\title{
PENGARUH PEKERJAAN ORANG TUA DAN KEYAKINAN DIRI TERHADAP MINAT BERWIRAUSAHA SISWA DI SMK NEGERI 10 SURABAYA
}

\author{
Dwi Indah Setyowati *
}

\begin{abstract}
This study aimed to determine the influences of parental employment and self-confidence of the students' interest on entrepreneurship in 10th State Vocational School of Surabaya, academic year 2012-2013. Populations of this study were 582 students and 106 samples were selected by using purposive sampling. Data were collected by questionnaires. Analysis technique was using multiple linear regression analysis. Partial results of the study concluded that the work of the parents has no influence on the interest in entrepreneurship, while self confidence has an influence of the students' interest in entrepreneurship. Simultaneously, this study concluded that parents work and self-confidence significantly influences students' interest in entrepreneurship students in 10th State Vocational School of Surabaya.
\end{abstract}

Keywords: Parental Work, Self Confidence and Interest in Entrepreneurship

\section{PENDAHULUAN}

$\mathrm{F}$ enomena yang ada diketahui bahwa minat siswa untuk berwirausaha di sekolah kejuruan yaitu di SMK Negeri 10 Surabaya masih sangat rendah. Banyak faktor yang menyebabkan rendahnya minat siswa dalam berwirausaha diantaranya yaitu pekerjaan orang tua dan keyakinan diri pada siswa. Keyakinan diri pada siswa, berdasarkan pada pengamatan bahwa siswa belum maximal dalam menjalankan praktek pada mata pelajaran kewirausahaan. Hampir sebagian siswa malu kalau mendapat giliran piket di businise center, koperasi sekolah, kantin apung dan kantin kejujuran. Hal ini dapat dikatakan bahwa keyakinan diri yang kurang pada siswa dapat menyebabkan rendahnya minat siswa untuk berwirausaha. Seperti yang diungkapkan oleh penelitian dahulu yang dilakukan oleh Fitriani ( 2012). Begitu pula dengan pekerjaan orang tua siswa yang sebagian besar dari orang tua bekerja sendiri menyebabkan anak tidak ingin seperti orang tua mereka sehingga minat anak untuk berusaha sendiri dalam arti berwirausaha masih rendah. Padahal karakter kerja orang tua adalah teladan anak.

Siswa SMK Negeri 10 Surabaya sebagian besar bertempat tinggal tidak jauh dari lokasi sekolah. Sedangkan lokasi dari SMK negeri 10 Surabaya berdekatan dengan pantai kenjeran. Pekerjaan orang tua antara lain nelayan, pemilik tambak atau bekerja ditambak. Tidak sedikit pula pekerjaan orang tua yang membuka usaha seperti toko, atau warung. Dalam arti banyak usaha atau pekerjaan yang bisa dibuka didaerah tersebut hal ini karena letak SMK Negeri 10 yang strategis yaitu disekitarnya terdapat banyak lembaga pendidikan seperti SMK swasta Adhikawacana, SMP dan SMA Yapita, SMA Negeri 20, SMP Negeri 19 Perguruan Tinggi Negeri ITS dan Pergruang Tinggi Swasta Hang Tuah.

*) Guru SMK Negeri 10 Surabaya 
Pekerjaan orang tua siswa pun beragam ada yang berwirausaha ada juga yang pegawai. SMK Negeri 10 Surabaya mempunyai program dan extrakulikuler yang harus diikuti oleh semua siswa diantaranya yaitu seperti bisinis center, kantin kejujuran, koperasi siswa, kantin apung, OSIS, PMR, pramuka, volly, basket, tari, drama, nyanyi, band dan masih banyak lagi. Untuk kantin kejujuran, koperasi siswa, business centre, kantin apung merupakan bentuk praktek dari mata pelajaran kewirausahaan yang wajib dilaksanakan oleh siswa. Dan siswa secara bergilir di jadwalkan ikut mengelolah usaha tersebut. Hal ini merupakan bentuk dari peran sekolah dalam menumbuhkan minat berwirausaha. Dari penjelasan diatas dapat disimpulkan bahwa minat berwirausaha dapat timbul dari pendidikan kewirausahaan yang dipelajari oleh siswa di sekolah. Hal ini sesuai dengan penelitian terdahulu yang dilakukan oleh Finisica Patrikha (2012). Agar supaya siswa menyukai hal hal baru yang belum diketahui, mempunyai inovasi dan dilatih untuk bertanggung jawab terhadap resiko yang ada. Selain itu keyakinan diri siswa juga harus ditumbuhkan agar supaya siswa dengan tingkat kesulitan ( level ) yang ada yang merupakan suatu tantangan dapat diselesaikan dengan ketepatan dalam cara berfikir. Ketahanan ( strenght ) dalam keyakinan diri siswa diperlukan kemampuan dan ketekunan agar siswa meraih kesuksesan. Keyakinan diri siswa juga perlu ditingkatkan agar siswa mempunyai keyakinan dimanapun dia berada dan dalam situasi dan aktivitas apapun.

Rendahnya minat berwirausaha, tidak hanya terjadi dikalangan siswa SMK Negeri 10 saja. Hampir sebagian besar masyarakat juga rendah minat berwirausahanya, hal ini sesuai pula dengan kompas, 21 September 20011 (dalam Kasmir, 2012:1) yang menyatakan jumlah wirausaha Indonesia hanya 0,24 persen dari jumlah penduduk, berarti jumlah tersebut masih sangat rendah. Hampir sebagian masyarakat Indonesia hanya berorientasi pada pencari kerja dan bukan berusaha untuk menciptakan lapangan pekerjaan sendiri. Setiap tahun beratus ratus atau berjuta juta orang ingin mencoba melamar menjadi karyawan di sebuah instansi yang dirasa sesuai dengan kemampuan yang di miliki, hanya sedikit orang yang berfikir untuk menciptakan lapangan pekerjaan. Selain itu persaingan dalam dunia kerja sangat ketat dikarenakan jumlah angkatan kerja yang banyak namun tidak diikuti jumlah lapangan pekerjaan, sehingga terjadi pengangguran. Tujuan dari Sekolah Menengah Kejuruan adalah siswa diharapkan mampu menciptakan lapangan pekerjaan dan diharapkan lulusan yang siap kerja dan memiliki peluang besar untuk ikut dalam ekonomi melalui kewirausahaan. Lulusan SMK diharapkan mendapat pekerjaan yang sesuai dengan keahlian yang dimiliki. Upaya untuk mengatasi pengangguran tersebut minimal harus ada perubahan dalam pola pikir masyarakat khususnya pada lulusan SMK dari mencari kerja menjadi menciptakan lapangan pekerjaan sendiri.

Namun demikian pada kenyataannya tidaklah mudah dalam memulai usaha. Untuk membentuk suatu manusia yang memiliki jiwa berwirausaha dan diharapkan mampu dalam berwirausaha, khususnya siswa SMK maka yang harus tertanam terlebih dahulu adalah minat berwirausaha itu sendiri. Sumarsini (2006:3) menyatakan pengertian minat berwirausaha adalah tertariknya seseorang untuk melakukan kegiatan usaha mandiri dengan keberanian mengambil resiko. Minat berwirausaha bisa datang dari dalam diri siswa itu sendiri maupun dari luar. Minat berwirausaha juga bisa timbul karena rasa ketertarikan dan kekaguman melihat kesuksesan orang dalam berwirausaha. Hasil penelitian yang dilakukan Lembaga Bina Karier (dalam Sumarni, 2006 ) bahwa calon wirausaha, mereka merasa perlu mengenali kepribadian dan kompetensi diri mereka sendiri. Hal ini akan sangat berguna dalam kehidupannya. 
Menurut pengamat pendidikan, Darmaningtyas dalam Merry (2008) ada kecenderungan semakin tinggi tingkat pendidikan semakin besar keinginan mendapat pekerjaan yang aman. Mereka tidak berani ambil pekerjaan beresiko seperti berwirausaha. Selain itu rasa takut yang berlebihan akan kegagalan dan kerugian karena keyakinan diri yang rendah menjadikan kesiapan orang dalam berwirausaha juga rendah. Walgito (2003:148) menyatakan minat berwairausaha tidak muncul begitu saja tetapi tumbuh dan berkembang sesuai dengan faktor faktor yang mempengaruhi. Beberapa faktor yang mempengaruhi minat berwirausaha diantaranya adalah keyakinan diri yang tinggi. Hal ini sesuai dengan kajian empirik dari Nuraeni (2012). Selain itu karakteristik kepribadian, faktor demografi dan karakteristik lingkungan, juga berpengaruh terhadap minat berwirausaha. Karakteristik lingkungan seperti lingkungan keluarga dan sekolah dapat menumbuhkan minat berwirausaha siswa. hal ini sesuai dengan penelitian terdahulu yang dilakukan oleh Finisica Patrikha (2012). Karakteristik kepribadian seperti keyakinan diri merupakan prediktor yang signifikan terhadap lahirnya minat berwirausaha. Keyakinan diri adalah kemampuan seseorang atas dirinya untuk menyelesaikan suatu pekerjaan. Keyakinan diri dapat mempengaruhi minat seseorang terhadap sesuatu hal yang dipercaya. Membuka sebuah usaha memerlukan kepercayaan terhadap kemampuan diri sendiri bahwa usahanya akan berhasil, hal inilah yang akan memotivasi seseorang untuk berani memulai usaha.ketertarikan sesorang dalam berwirausaha ini seperti penelitian terdahulu yang dilakukan oleh Clement K (2004 ). Motivasi sesorang dalam keberanian membuka usaha ini sesuai dengan penelitian yang dilakukan Aminati (2009). Apabila seseorang tidak percaya akan kemampuan yang dimiliki, kemungkinan sangat kecil orang tersebut untuk berminat dalam berwirausaha. Luthans (2008:205) dalam sembilan meta analisisnya juga menemukan, bahwa keyakinan diri juga mendorong kinerja seseorang dalam berbagai bidang termasuk minat berwirausaha. Sedangkan keyakinan diri menurut Kreitner dan Kinicki ( dalam Engko, 2006 ) adalah keyakinan seseorang mengenai peluang untuk berhasil mencapai tugas tertentu, yang mana seorang siswa harus mempunyai keyakinan diri yang tinggi untuk dapat mencapai kariernya nanti.

Tumbuhnya minat berwirausaha tidak lepas juga dari pengaruh lingkungan keluarga siswa sebagai salah satu faktor yang ikut mendukung. Lingkungan keluarga terutama orang tua yang berwirausaha jelas sekali berperan sebagai pengarah bagi masa depan anaknya, sehingga secara tidak langsung orang tua juga mempengaruhi minat terhadap pekerjaan bagi anak dimasa yang akan datang termasuk dalam berwirausaha. Hal ini sesuai dengan penelitian terdahulu yang dilakukan oleh Aditya Dion Mahesa (2012). Selain itu pula dalam keluarga pekerjaan orang tua juga dapat mempengaruhi minat anak untuk berwirausaha seperti penelitian yang dilakukan oleh Mica Siar ( 2012). Kondisi orang tua sebagai keadaaan yang ada dalam lingkungan keluarga dapat menjadi figur bagi pemilihan karier anak juga sekaligus dapat dijadikan sebagai pembimbing untuk menumbuh kembangkan minatnya terhadap suatu pekerjaan (Sumarni, 2006). Minat wirausaha berkembang pada diri seseorang bila lingkungan mendukung karena minat terbentuk dari lingkungan keluarga. Pendidikan berwirausaha dapat berlangsung sejak dini dalam lingkungan keluarga

"Having a mother or father who is self employed provide a strong inspiration for entrepreneur. The independent nature and flexibility of self-employment is ingrained at an early age " (Hisrich et al.,2005:65)

Memiliki seorang ibu dan ayah yang berwirausaha memberikan inspirasi kepada 
anak untuk menjadi wirausahawan. Fleksibilitas dan kemandirian dari wirausahawan telah mendarah daging pada anak sejak dini. Anak terinspirasi untuk berwirausaha karena melihat kesungguhan dan kerja keras ayah dan ibunya. Anak juga terinspirasi Alma (2010:9) karena memang dilatih sejak kecil, dimintai bantuan mulai dari pekerjaan yang ringan atau mudah sampai yang rumit dan kompleks. Terlatih dan terinspirasinya sehingga mempengaruhi minatnya dalam berwirausaha. Melalui keluarga pola pikir kewirausahaan terbentuk.

Minat berwirausaha tumbuh dan berkembang dengan baik pada seseorang yang hidup dan tumbuh dilingkungan yang pekerjaan orang tuanya sebagai wirausaha. Kenyataan sebagian besar lingkungan keluarga belum kondusif dalam pembentukan minat anak dalam berwirausaha. Hal ini disebabkan oleh beberapa faktor antara lain keterbatasan pengetahuan orang tua tentang berwirausaha, pola pikir orang tua untuk menjadi PNS atau karyawan yang lebih aman dari pada menjadi wirausahawan dan juga tidak adanya model wirausahawan pada keluarganya. Menurut bahwa faktor yang dapat mendorong untuk membuka usaha atau menjadi wirausaha dipengaruhi oleh dorongan dari keluarga, pengalaman, keadaan ekonomi, keadaan lapangan kerja dan sumber daya yang tersedia. Lingkungan keluarga yang dapat mempengaruhi seseorang untuk menjadi wirausaha dapat dilihat dari segi faktor pekerjaan orang tua. faktor pekerjaan orang tua ini dapat mempengaruhi minat siswa dalam berwirausaha seperti yang diungkaupakan oleh penelitian terdahuli yaitu Caecilia (2012). Pekerjaan orang tua sering kali terlihat bahwa ada pengaruh dari orang tua yang bekerja sendiri, dan memiliki usaha sendiri maka cenderung anaknya akan menjadi pengusaha (Alma, 2010:8).

Berdasarkan kajian pustaka diatas, peneliti merumuskan hipotesa sebagai berikut:

1. Diduga ada pengaruh pekerjaan orang tua terhadap minat berwirausaha siswa di SMK Negeri 10 Surabaya.

2. Diduga ada pengaruh keyakinan diri terhadap minat berwirausaha siswa di SMK Negeri 10 Surabaya.

3. Diduga ada pengaruh pekerjaan orang tua dan keyakinan diri terhadap minat berwirausaha siswa di SMK Negeri 10 Surabaya.

\section{METODE PENELITIAN}

Pendekatan yang dilakukan dalam penelitian ini adalah pendekatan kuantitatif. Sedangkan variabel yang digunakan adalah pekerjaan orang tua (X1 ), keyakinan diri (X2), serta minat berwirausaha (Y).

Populasi dalam penelitian ini adalah siswa SMK Negeri 10 Surabaya kelas XI tahun ajaran 2012 - 2013 sebanyak 582 siswa dengan jumlah sampel sebanyak 106 yang diambil dari kelas XI jurusan pemasaran. Diambil sampel kelas XI karena pada kelas ini materi pelajaran kewirausahaan dibahas lebih dalam dan dikelas ini siswa mendapat materi praktek kewirausahaan. Dan diambil jurusan pemasaran karena materi prakteknya lebih banyak diprogramkan di SMK Negeri 10 Surabaya. Data dikumpulkan melalui kuesioner yang disusun berdasarkan variabel penelitian dan indikator penelitian dengan skala pengukuran instrumen menggunakan skala likert. Tehnik analisa menggunakan analisis uji statistik yaitu uji F dan uji t. Uji F digunakan untuk menguji signifikan variabel pekerjaan orang tua dan keyakinan diri terhadap minat berwirausaha. Uji t digunakan untuk menguji 
signifikan pengaruh pekerjaan orang tua terhadap minat berwirausaha, pengaruh keyakinan diri terhadap minat berwirausaha.

\section{HASIL PENELITIAN DAN PEMBAHASAN}

Uji asumsi klasik meliputi uji normalitas, multikolinieritas dan heteroskedastisitas.

\section{Uji Normalitas}

Uji normalitas mengunakan cara uji kolmogorov-smirnov. Adapun tujuan melakukan uji normalitas adalah untuk menguji bahwa sampel telah mewakili populasi. Sehingga hasil penelitian dapat digeneralisasikan pada populasi. Uji kolmogorov sebesar 1,275 dengan taraf signifikan 0,077 lebih besar dari 0,05 berarti data berdistribusi normal.

2. Uji Multikolinieritas

Salah satu cara menditeksi multikolinieritas adalah dengan melihat nilai tolerance dan nilai VIF (Variance Inflaction Factor) yang diperolehnya. Hasil uji multikolinieritas dalam penelitian ini adalah nilai VIF pada variabel pekerjaan orang tua (X1) dan keyakinan diri (X2) diperoleh nilai sebesar 1,012 dimana nilai tersebut kurang VIF $=10$ dapat dikatakan bahwa antara variabel bebas tidak terjadi multikolinieritas.

3. Uji Heterokedastisitas

Untuk mengkorelasikan variabel bebas dengan nilai residualnya maka dilakukan pengujian heterokedastisitas dengan melihat koefisien korelasi rank spearman. Uji heteroskedastisitas menjelaskan bahwa antara variabel bebas dengan residual tidak terjadi heteroskedastisitas, hal ini terlihat dari tingkat signifikan yang dihasilkan oleh variabel pekerjaan orang tua (X1) sebesar 0,631 melebihi 5\% dan tingkat signifikan yang dihasilkan oleh variabel keyakinan diri (X2) sebesar 0,844 melebihi $5 \%$.

4. Uji Linieritas

Untuk mengetahui status linier atau tidaknya suatu distribusi data penelitian, atau diakatakan apakah antar dependent varibel dan independent variable tersebut linier maka digunakan uji lineritas.. Hasil yang diperoleh pada uji linieritas menentukan teknik Anareg (Analisa Regresi) yang akan digunakan. Bila dari hasil uji linieritas didapatkan kesimpulan bahwa distribusi pada penelitian dikatagorikan linier, data penelitian diselesaikan dengan teknik Anareg linier. Bila ternyata tidak linier maka distribusi data penelitian harus dianalisis Anareg non linier. Teknik yang digunakan untuk menguji, menggunakan model Curve Fit dan table Anova. Bila p linieritas $<0,05$ dapat dikatakan linier, berarti variabel bebas termasuk layak sebagai salah satu predictor variable terikat, demikian juga sebaliknya.

Model regresi yang diperoleh berdasarkan hasil penelitian, dapat dituliskan dalam bentuk persamaan regresi sebagai berikut $\mathrm{Y}=2,065+0,080 \mathrm{X} 1+0,554 \mathrm{X} 2+\mathrm{e}_{\mathrm{i}}$. Dari persamaan diatas, menunjukkan bahwa keyakinan diri memiliki hubungan yang searah dengan minat berwirausaha yaitu semakin tinggi keyakinan diri maka semakin tinggi minat berwirausaha. Hasil uji F berdasarkan uji ANOVA atau uji statistik F, model menunjukkan nilai $\mathrm{F}$ sebesar 37,622 dengan probabilitas sebesar 0,000. Besarnya pengaruh pekerjaan orang tua dan keyakinan diri terhadap minat berwirausaha dapat dilihat dari koefisien determinasi (R-square) yaitu sebesar $42,2 \%$ yang berarti pekerjaan orang tua dan keyakinan diri secara simultan mampu mempengaruhi minat berwirausaha sebesar $42,2 \%$ sedangkan $57,8 \%$ dipengaruhi oleh variabel lainnya. 
Lebih lanjut uji parsial menunjukkan nilai t-hitung pada variabel pekerjaan orang tua sebesar 1,024 dengan tingkat signifikan lebih dari 5\% yaitu 0,308. Hal ini berarti pekerjaan orang tua secara parsial tidak berpengaruh signifikan terhadap minat berwirausaha. Nilai t-hitung pada variabel keyakinan diri sebesar 8,447 dengan tingkat signifikan kurang dari 5\% yaitu 0,000 . Hal ini berarti keyakinan diri secara parsial berpengaruh signifikan terhadap minat berwirausaha.

\section{Pembahasan}

1. Pengaruh pekerjaan orang tua terhadap minat berwirausaha.

Berdasarkan hasil penelitian mengenai pengaruh pekerjaan orang tua terhadap minat berwirausaha menunjukkan bahwa pekerjaan orang tua tidak berpengaruh terhadap minat berwirausaha. Hipotesia kerja yang menyatakan diduga ada pengaruh pekerjaaan orang tua terhadap minat berwirausaha siswa kelas XI SMK Negeri 10 Surabaya tidak teruji kebenarannya. Hal ini ditunjukkan melalui hasil persamaan regresi linier berganda diperoleh nilai t-hitung pada variabel pekerjaan orang tua (X1) sebesar 1,024 dengan tingkat signifikan lebih dari $5 \%$ yaitu 0,308 . Hal ini berarti pekerjaan orang tua (X1) tidak berpengaruh terhadap minat berwirausaha (Y). Dalam hasil penelitian ini ditemukan bahwa pekerjaan orang tua tidak berpengaruh terhadap minat berwirausaha siswa. hasil ini bertentangan dengan kajian teori Alma (2010:8 ) yang menyetakan bahwa pekerjaan orang tua sering kali terlihat ada pengaruh dari orang tua yang bekerja sendiri. Temua ini juga tidak sesuai dengan Hisrich et al ( 2005:6) yang menyatakan bahwa memilki seorang ibu dan ayah yang berwirausaha memberikan inspirasi kepada anak untuk menjadi wirausaha. Tetapi hasil penelitian ini sesuai dengan kajian empiris yaitu penelitian terdahulu yang dilakukan oleh Merry (2010) bahwa latar belakang pekerjaan orang tua tidak memiliki peran dalam menentukan minat berwirausaha. Dari penelitian ini ditemukan data responden pekerjaan orang tua siswa yang berwirausaha $91,51 \%$ dan yang non wirausaha $8,49 \%$.

\section{Pengaruh Keyakinan Diri terhadap Minat Berwirausaha.}

Berdasarkan hasil penelitian mengenai pengaruh keyakinan diri terhadap minat berwirausaha menunjukkan bahwa keyakinan diri berpengaruh signifikan terhadap minat berwirausaha. Hipotesa kerja yang menyatakan diduga ada pengaruh keyakinan diri terhadap minat berwirausaha siswa kelas XI SMK Negeri 10 Surabaya, teruji kebenarannya. Hal ini ditunjukkan melalui hasil persamaan regresi linear berganda diperoleh nilai t-hitung pada variabel keyakinan diri ( X2 ) sebesar 8,447 dengan tingkat signifikan kurang dari $5 \%$ yaitu 0,000 . Hal ini berarti keyakinan diri (X2) berpengaruh terhadap minat berwirausaha ( Y ). Dari hasil penelitian ditemukan ada pengaruh keyakinan diri terhadap minat berwirausaha siswa. Hasil penelitian ini sesuai dengan teori yang dinyatakan Luthans ( 2008:202) mendefinisikan keyakinan diri sebagai keyakinan individu atau kepercayaan tentang kemampuannya untuk menggerakkan motivasi, sumber daya kognitif dan cara bertindak yang diperlukan untuk berhasil melaksanakan tugas dalam konteks tertentu, disini juga dibutuhkan ketrampilan kepemimpinan dan kematangan mental. Schultz dan Schultz (2006:360), mendefinisikan keyakinan diri sebagai kepercayaaan terhadap kemampuan seseorang untuk menyelesaikan suatu tugas. Hasil penelitian ini juga didukung oleh kajian empirik dari penelitian terdahulu yaitu menurut Nastiti (2011), menyimpulkan bahwa : terdapat pengaruh efficacy pribadi terhadap minat berwirausaha. Serta Lukmayanti (2011), dengan hasil penelitian terdapat hubungan yang signifikan antara efikasi 
diri dengan minat berwirausaha siswa kelas XII program Keahlian Jasa Boga Di SMK Negeri 6 Yogyakarta.Dari hasil penelitian ini ditemukan faktor lingkungan sekolah dan masyarakat ditemukan mempunyai pengaruh terhadap keyakinan diri siswa. lingkungan sekolah seperti aktif dalam kegiatan pembelajaran yaitu disiplin dalam mengikuti kegiatan kewirausahaan dan juga aktifbdalam kegiatan ektrakulikuler. Lingkingan masyarakat yang berperan dalam meningkatkan keyakinan diri siswa terhadap minat berwirausaha adalah perusahaan tempat siswa melakukan On the Job Training.

\section{Pengaruh Pekerjaan Orang Tua Dan Keyakian Diri Terhadap Minat Berwirausaha.}

Berdasarkan hasil penelitian pekerjaan orang tua dan keyakinan diri berpengaruh signifikan terhadap minat berwirausaha. Hipotesa kerja yang menyatakan diduga ada pengaruh pekerjaan orang tua dan keyakinan diri terhadap minat berwirausaha siswa kelas XI SMK Negeri 10 Surabaya, teruji kebenarannya. Hal ini dapat dilihat dari hasil uji F diperoleh nilai $\mathrm{F}$ hitung yaitu 37,622 dengan tingkat signifikan kurang dari 5\% yaitu 0,000. Maka pekerjaan orang tua (X1) dan keyakian diri (X2) secara simultan berpengaruh signifikan terhadap minat berwirausaha ( Y ). Besarnya pengaruh pekerjaan orang tua dan keyakian diri terhadap minat berwirausaha dapat dilihat dari R-square yaitu sebesar $42,2 \%$. Yang berarti pekerjaan orang tua dan keyakinan diri secara simultan mampu mempengaruhi minat berwirausaha sebesar 42,2\% sedangkan 57,8\% dipengaruhi oleh variabel lainnya. Hasil penelitian ini didukung oleh penelitian Mahesa (2012), menyimpulkan bahwa: Keberhasilan diri dalam berwirausaha berpengaruh positif terhadap minat berwirausaha dan Latar belakang pekerjaan orang tua berpengaruh positif terhadap minat berwirausaha. Minat berwirausaha disini adalah rasa tertariknya seseorang untuk melakukan kegiatan usaha yang mandiri dengan keberanian mengambil resiko. Sedangkan indikator yang ada pada minat berwirausaha adalah tertarik pada hal hal baru, berani mengambil resiko dan inovatif. Dan berdasarkan jawaban responden ditemukan minat berwirausaha pada diri siswa di SMK Negeri 10 Surabaya adalah sangat tinggi yaitu rata rata sebesar 4,68. Ini menunjukkan tingginya ketertarikan akan hal hal baru, tingginya keberanian siswa dalam mengambil resiko dan tingginya inovatif pada siswa.

\section{KESIMPULAN}

Dari pembahasan yang telah diuraikan, maka dapat ditarik kesimpulan sebagai berikut:

1. Pengaruh pekerjaan orang tua terhadap minat berwirausaha siswa SMK Negeri 10 Surabaya tidak signifikan. Ternyata pekerjaan orang tua tidak berpengaruh pada minat berwirausaha siswa SMK Negeri 10 Surabaya. padahal sebagian besar pekerjaan orang tua adalah berwirausaha.

2. Pengaruh keyakinan diri terhadap minat berwirausaha siswa SMK Negeri 10 Surabaya adalah signifikan. Semakin tinggi keyakinan diri maka semakin tinggi minat berwirausaha siswa SMK Negeri 10 Surabaya.

3. Pengaruh pekerjaan orang tua dan keyakinan diri terhadap minat berwirausaha siswa SMK Negeri 10 Surabaya adalah signifikan. Semakin tinggi pengaruh pekerjaan orang tua dan keyakinan diri maka semakin tinggi minat berwirausaha siswa SMK Negeri 10 Surabaya. 
Saran yang dapat diberikan sebagai tindak lanjut dari hasil penelitian adalah sebagai berikut:

1. Berdasarkan penelitian ditemukan pekerjaan orang tua tidak berpengaruh terhadap minat berwirausaha, maka disarankan orang tua seharusnya melibatkan langsung anak anak mereka di dalam kegiatan usahanya yang disesuaikan dengan kemampuan anak. Dalam penelitian ini peneliti juga menyarankan untuk peneliti selanjutnya untuk menggunakan variabel lain seperti penghasilan orang tua serta pendidikan orang tua.

2. Karena keyakinan diri pada siswa SMK Negeri 10 Surabaya sangat tinggi, hendaknya bapak dan ibu guru serta pihak sekolah terus berupaya meningkatkan keyakianan diri dengan mengembangkan kegiatan ekstrakulikuler.

\section{DAFTAR RUJUKAN}

Alma, B. 2010. Cara Kewirausahaan untuk mahasiswa dan umum. Bandung: Alfabeta.

Dion Mahesa, Aditya, 2012. Analisis Faktor Faktor Motivasi Yang Memepengaruhi Minat Berwirausaha. Jurnal Universitas Diponegoro

Engko, Cecilia. 2006. Pengaruh Kepuasan Kerja Terhadap Kinerja Dengan Self Esteem dan Self Efficacy Sebagai Variabel Interverning. Simposium Nasional Akuntansi 9 Padang.

Fitriani, Aprilia, 2012. Faktor Faktor Yang Mempengaruhi Minat Berwirausaha Pada Siswa Kelas XII SMK Negeri 1 Kandeman Kabupaten Batang. Economic Education Analysis Journal, Universitas Negeri Semarang.

Hisrich, R.D.,Peters,M.P \& Shepherd,D.a. 2008. Kewirausahaan ( edisi 7) ( terjemahan Chriswan Sungkono\& Diana Angelica) Karakter Kerja Orang Tua, Keteladanan Bagi Anak, http://www.sahabatnestle.co.id/Page/hidup/gaya/ibu/karakter kerja.

Kasmir,2012. Kewirausahaan edisi Revisi. Jakarta: PT RAJAGRAFINDO PERSADA.

Luthans F, 2008. Prilaku Organisasi. Jogyakarta: penerbit Andy.

Lukmayanti, Arista. 2011. Hubungan Efficacy Diri dengan Minat Berwirasaha Siswa Kelas XII Program keahlian Jasa Boga di SMK Negeri 6 Yogyakarta

Meiriza, Mica Siar, 2012. Hubungan Antara Pelaksanaan Mata Kuliah Bahasa Inggris Bisnis Dengan Mempertimbangkan Gender dan Latar Belakang Pekerjaan Orang Tua. Jurnal Universitas Negeri Medan

Nuraeni, 2012. Pengaruh Kebutuhan Akan Prestasi dan Efikasi Diri Terhadap Minat Berwirausaha.

Nastiti, Tur. 2011. Minat Berwiraswasta Mahasiswa Indonesia Dan Cina.

Patrikha, Finisica, 2012. Pengaruh Pendidikan Kewirausahaan dalam Keluarga dan di sekolah Terhadap Minat Berwirausaha Melalui Self Efficacy Siswa SMK di Kota Malang. jurnal Pascasarjana UM.

Sumarni,2006. Pengaruh Konsep Diri, Prestasi Belajar Dan Lingkungan Terhadap Minat 
Berwirausaha Pada Siswa SMK Negeri 2 Semarang." Skripsi Fakultas Ilmu Sosial Jurusan Ekonomi Universitas Negeri Semarang

Vemmy, Caecilia,2012. Faktor Faktor Yang Mempengaruhi Intensi Berwirausaha Siswa SMK. Jurnal Universitas Negeri Yogyakarta.

Wang.Clement K. Poh- Kam Wong.2004. Entrepreneurial interest of university students in singapore. Centre forEntrepreneurship. National university of Singapore, Singapore

Walgito, bimo.2003. Pengantar Pendidikan.Malang: Fakultas Ekonomi UIN Maliki Malang 